Розділ І. Ціннісні орієнтири духовно-інтелектуального виховання, розвиток духовно-інтелектуальних якостей особистості в умовах співпраці й інклюзії

\title{
ОДИН 3 ПІДХОДІВ ДО ВИВЧЕННЯ НОВИХ СЛІВ АНГЛІЙСЬКОЇ МОВИ ЧЕРЕЗ МНЕМОНІЧНІ АСОЦАЦІї
}

\author{
Мандражи О. А. \\ кандидат педагогічних наук,
}

Державний біотехнологічний університет, м. Харків, Україна

У статті на основі вивчення мнемонічних асоиіацій, які пропонуються на курсах 3 «Оволодіння англійською мовою» $i$ базуються на придумуванні для кожного слова якої-небудь яскравої мітки через сюжетні картинки, подається власний підхід для легкого запам'ятовування нових слів англійської мови через спорідненість та схожість їх значення і вимови з українськими словами.

Ключові слова: англійська мова, вивчення нових слів, мнемонічні acoụiau̧ï.

The article author presents her own approach to memorizing new English words. This approach means mnemonic associations that are used in teaching "Mastering the English Language" and are based on inventing a bright mark for each word through the thematic pictures. This approach is built on affinity and likeness of meaning and pronunciation of English and Ukrainian words, and it helps to memorize new English words easier.

Key words: English, learning new words, mnemonic associations.

Розвиток української сучасної освіти наразі знаходиться під потужним впливом багатьох факторів. Серед основних можна виокремити внутрішні соціально-політичні зміни у нашій країні, процес світової інтеграції, спалах пандемії коронавірусної інфекції, яка зумовила активне застосування онлайн освіти. Отже, необхідним на часі стає і збереження того найкращого, що вже є у нашій освітянській скарбничці, і розвиток власних нових підходів, методів і технологій навчання, що відповідають сучасним викликам, і вбирання найкращого досвіду зарубіжних колег, при впровадженні якого важливими мають стати продуманість і вираховування світогляду та духовного розвитку, притаманних для нашої нації.

Усе вищезазначене зумовлює той факт, що знання англійської мови, як однієї з основних мов міжнародного спілкування, сприймається вже не стільки як рівень освіченості людини, скільки як необхідність. Освітяни й люди інших професій, що не є за фахом лінгвістами, ви- 
вчають іноземну мову, щоб впевненіше почуватися у сьогоденних реаліях.

У педагогіці є багато різноманітних методів і підходів до вивчення іноземних мов, навіть пропонуються навчання уві сні, сублімаційні способи вивчення мови, ритмічне заучування фраз тощо. І все ж, якими б не були методики, вони не звільняють нас від необхідності заучування великої кількості іншомовних слів. Ця стаття розкриває власний досвід автора стосовно того, яким чином можна для себе полегшити даний процес.

Поширеною є теза про те, що діти легко засвоюють як рідну, так й іноземну мови. Серед науковців дане твердження є суперечливим, але прихильники вищезазначеної тези пояснюють їі дитячою нелогічністю розмірковувань, їхнім сприйняттям світу, яке ще не запорошено умовностями, стереотипами і штампами. На цій ідеї базується, наприклад, технологія курсів 3 «Надшвидкого оволодіння англійською мовою» за методом Пауля Пімслера [1]. Описуючи власну технологію, доктор П. Пімслер наголошує на тому, що зазвичай для вивчення нових іншомовних слів ми складаємо їхній список і просто заучуємо його. Коли ж ми пригадуємо переклад слів, перше, що найчастіше уявляємо, це місце розташування слова у нашому списку - спрацьовує зорова пам'ять. Описане не є особливістю нашої пам'яті, просто у неї немає можливості зачепитися за щось більш істотне. Методика для запам'ятовування слів за П. Пімслером пропонує кожному слову для кращого запам'ятовування надавати яскраву відмінність, щоб позбутися одноманітності, і тоді слова будуть запам'ятовуватись мимоволі. Для досягнення яскравої відмінності пропонується застосовувати мнемонічні асоціації, при створенні яких обов'язково маніпулювати і значенням слова, і його вимовою. Застосування мнемонічних асоціацій пов'язується 3 кількома вимогами. Запам'ятовування слів не має бути метою при вивченні іноземної мови, воно має бути тільки дією, що наближає до досягнення мети. Важливим $є$, звісно, націленість на вивчення мови. Окрім того, наголошується, що перед тим, як почати запам'ятовування нових слів, необхідно впевнити себе і щиро повірити, що ви хочете вивчити дані слова, що ви їх запам'ятаєте надовго, і нагадується, що вище описане налаштування на роботу, діяльність, якесь заняття забезпечувалось молитвою. Наприклад, молитва, прочитана перед обідом або заняттям, заспокоювала, відсувала турботи, 
Розділ І. Ціннісні орієнтири духовно-інтелектуального виховання, розвиток духовно-інтелектуальних якостей особистості в умовах співпраці й інклюзії

сприяла кращому засвоєнню їжі або знань. Також підкреслюється, що людина краще запам'ятовує, коли об'єкт не статичний, а динамічний. Дана вимога підтверджується проведеними експериментальними дослідженнями, які уможливлюють висновок: усі образи, що використовуються для запам'ятовування іноземних слів, мають бути динамічними, оскільки саме це дозволяє інформації, що вивчається, запам'ятовуватись надовго. Робиться узагальнення, що мову не треба зазубрювати механічно, а необхідно спиратись на звичку, власну логіку, власне сприйняття світу. Щоб позбавити список слів одноманітності, необхідно надати кожному слову яку-небудь яскраву мітку, оскільки слово, за методикою доктора П. Пімслера, краще запам'ятовується не стільки через повторення, скільки за допомогою сюжетних картинок. Слова будуть запам'ятовуватись мимоволі, якщо не запам'ятовування буде нашою метою, а уявні операції із значенням і вимовою слова, саме вони мають безпосередньо включатись у мету навчання.

Отже, основою описаної вище методики стає уявне маніпулювання словами, а саме, коли до іноземного слова підбирається схоже за звучанням слово рідної мови. Наприклад, пропонується розглянути слово sleeve (рукав, англ.) — за звучанням є схожим на «слив», тобто можна розглянути асоціацію зі словом «слива» та додати динамічний образ: уявити, як продавець у магазині зваживши сливи, перекладає їх у порожній рукав, оскільки уява дозволяє слову з короткочасної пам'яті одразу зафіксуватися у довгостроковій (задіяне образне мислення). Ще раз звертається увага на тому, що продавець зважує, насипає у довгий рукав, тобто кожне слово у списку для вивчення таким чином знаходить незвичне відношення між словами, яке є яскраво емоційно зафарбленим, стає індивідуальним, відмінним від інших. Описана асоціація творчий процес, на який дійсно слід налаштуватись, оскільки він потребує нестандартного мислення. Наводяться й інші приклади асоціацій: chess (чесати) шахи, finger (фінгал) палець, knock (нога) стукати. Узагалі, мнемонічні асоціації доволі часто пропонуються слухачам сучасних курсів з вивчення англійської з метою поповнення їхнього лексичного запасу. При цьому завжди наголошується, що важливим моментом $є$ те, що асоціації та пов'язані з ними динамічні картинки мають бути смішними, гостро емоційними, навіть провокаційними, іноді безглуздими та перебільшеними - саме це і $є$ запорукою успіху. Мета, налаштованість, динамічність - усе це має місце при створен- 
ні власної динамічної картинки, але важливо, що ці картинки - не просто якісь неймовірні асоціації, а образи, створені на родинності зав'язків між словами різних мов. Наприклад, слово sleeve промовляється як «слив» і у перекладі з англійської означає рукав, отже, необхідно пригадати, де слово «рукав» пов' язане зі словом «слив». Одразу 3'являється динамічна, яскрава і неодноманітна картинка 3 пожежним рукавом або рукавом річки. Тобто sleeve [слив] - рукав. У нас пожежні рукави якраз і призначені для води (для переміщення, зливу води). Можна уявити, як вода зливається у цьому рукаві.

I таких споріднених асоціацій можна навести доволі багато. Наведемо приклади деяких із них.

Sleep [сліп] - спати. Коли ми засинаємо, то кажемо злипаються очі.

Pocket [покит] — кишеня. I у нас кишеня асоціюється 3 тим, що ми можемо в нього покидати усе, що заманеться.

Wall [во(а)л] — стіна. Дуже схоже з нашим українським словом «вал» у значенні або як довга купа сіна, в яку згрібається покіс, або як довгастий насип земляних порід — кожне $з$ порівнянь нагадує стіну.

Cup [кап] — чашка. Ми у чашку щось наливаємо, капаємо. Чашка за своїм функціональним призначенням могла і для нас мати назву «кап».

Knit [нит] — в'язати. У нас в'яжуть нитками.

Cut [кат] — різати, розділяти. Українська має схоже за суттю слово - катувати.

Lie [лай] — обман, брехня. Лай, як лай собаки, а українською ми кажемо, що «собака бреше».

Sheep [щип] - овечка. Овечка щипає травичку.

Виходячи з власного досвіду, можемо стверджувати, що таким чином знаходиться своєрідна схожість для усіх найпоширеніших слів англійської мови. До речі, сама по собі націленість на знаходження картинок зі спорідненістю за вимовою і значенням слів є дуже цікавою, та і слова при цьому дійсно легко запам'ятовуються, адже з'являється враження, що усі мови десь таки мають спільне коріння і від усвідомлення цього приходить натхнення вивчити ще більше слів, тобто знайти ще більше спільного. Окрім того, даний підхід сприяє розвитку творчого мислення.

\section{Список використаних джерел:}

1. Сверхбыстрое овладение английским языком по методу доктора Пимслеpa. URL : https://fenglish.ru/sverxbystroe-ovladenie-anglijskim-yazykom-pometodu-doktora-pimslera/ (дата звернення: 07.10.2021). 